\title{
Profil Darah pada Kucing Selama Proses Kesembuhan Luka Melalui Teknik Skin Flaps Rotasi yang Dirawat dengan Dry Dressing dan Moist Dressing
}

\author{
Blood Profile of Cats during the Wound Healing Process using the Rotation Flap \\ with both Dry and Moist Dressing
}

\section{Erwin Erwin $^{1{ }^{*}}$, Rusli Rusli ${ }^{1}$, Fidella Diva Jones ${ }^{2)}$}

${ }^{1)}$ Laboratorium Klinik dan Bedah Fakultas Kedokteran Hewan, Jln. Teungku Hasan Krueng Kalee No.4, Universitas Syiah Kuala, Banda Aceh

${ }^{2}$ Program Studi Pendidikan Dokter Hewan Fakultas Kedokteran Hewan, Jln. Teungku Hasan Krueng Kalee No.4, Universitas Syiah Kuala, Banda Aceh

Article history

Received: Jan 9, 2020;

Accepted: Mar 3, 2020

* Corresponding author:

E-mail:

erwin2102@unsyiah.ac.id

DOI: https://doi.org/10.46549 /jipvet.v10i1.83

\section{Abstract}

The skin flap is one of the techniques employed to reconstruct defects and close wounds. This study aims to observe the blood profile in cats during the healing process of rotation skin flaps that were treated with a dry and moist dressing. This study used six male cats within the age of 1-2 years old and weighed among 2-4 kg, divided into two treatment groups. All of the specimens were treated with the following procedure; the fur on the abdominal area was shaved and disinfectant was applied to the area between the os sacrum and os femur, lastly, $2 \mathrm{~cm} 2$ triangle wound was deliberately made on the area. The treatment of the wound was done by the rotation skin flaps method. Group 1 was treated with sterile bandage and group 2 was treated with sofratulle ${ }^{\circledR}$. Blood samples were taken from the cephalica antebrachii vein on the 1st, 3rd, 6th, and 12th days. The erythrocytes, hemoglobin, hematocrit, platelets, leukocytes, neutrophils, basophils, eosinophils, monocytes, and lymphocytes were counted by hematology analyzer. The results showed that there is a significant difference $(\mathrm{P}<0.05)$ in the increase of neutrophil levels between the group treated with sterile kassa $(\mathrm{P}-1)$ and the group treated with sofratulle ${ }^{\circledR}(\mathrm{P}-2)$. The number of the cats' red blood cells rose on the 3rd day and rose again on the 12th day after the treatment with a significant difference $(\mathrm{P}<0.05)$ during the observation. In conclusion, the rotation flaps treatment method with dry dressing and moist dressing in the wound healing process affected the cats' blood profile and the moist dressing was preferred to the dry dressing.

Keywords: Rotation flaps; Cat; Dry dressing; Moist dressing; Blood profile

\section{PENDAHULUAN}

Luka didefinisikan sebagai gangguan kontinuitas pada lapisan epitel kulit atau mukosa akibat kerusakan fisik atau termal (Dhivya et al., 2015). Luka dengan kehilangan jaringan yang cukup luas membutuhkan jaringan penutup untuk mengatasinya. Metode yang tersedia untuk menutup luka adalah dengan jahitan, perekat jaringan dengan dressing, dan skin graft/skin flaps (Lawrence dan Tierney, 2002). Skin flaps adalah salah satu teknik bedah untuk menutupi luka pada kulit, dimana flaps ditarik dari suatu bagian tubuh ke bagian tubuh lain dan masih memiliki hubungan suplai darah dengan jaringan asal (Langley-Hobbs et al., 2014). Berdasarkan suplai darah flaps diklasifikasikan menjadi local skin flaps dan distance skin flaps. Local skin flaps dibagi menjadi rotating flaps dan advancement flaps (Smith, 2010). Penutupan luka dengan jahitan dan dressing dapat menahan luka dengan baik dan meminimalkan masuknya benda asing (Schulitz et al., 2005). Dressing merupakan bahan yang digunakan secara topikal pada luka (Galiano, 2007) diklasifikasikan menjadi perban tradisional, 
biologis, dan buatan (Kamoun et al., 2017). Salah satu produk perban tradisional seperti kassa termasuk dry dressing (Boateng et al., 2008), sedangkan moist dressing merupakan produk tulle grass (kassa steril) yang mengandung framycetin sulphate 1\% (Carville, 2012) dengan kondisi lembab. Produk ini melindungi luka dengan menyediakan lingkungan luka yang lembab (Wijaya, 2018). Kesembuhan luka secara klinis terlihat dengan bertemunya kedua tepi luka dan adanya vaskulariasasi yang sehat pada daerah penempelan luka merupakan penentu keberhasilan teknik skin flaps (Erwin et al., 2016). Pembentukan dan perkembangan pembuluh darah baru atau angiogenesis serta terdapatnya bekuan darah merupakan hal yang sangat berpengaruh pada proses penyembuhan luka (Mast, 2000).

Pemeriksaan darah sebelum dan sesudah bedah menggambarkan kondisi tubuh secara sistemik. Kehilangan darah setelah bedah skin flaps menyebabkan dehidrasi yang berpengaruh pada gambaran eritrosit kucing. Trombosit berperan sebagai lem biologis untuk mempertautkan skin flaps, leukosit berperan sebagai sel pertahanan untuk mengeliminasi antigen asing dalam proses kesembuhan skin flaps. Penelitian ini dilakukan untuk mengamati profil darah kucing selama proses kesembuhan skin flaps rotasi yang dirawat dengan $d r y$ dressing dan moist dressing. Hasil penelitian diharapkan dapat memberi informasi mengenai profil darah kucing selama proses kesembuhan luka skin flaps rotasi dan perban yang baik digunakan dalam perawatan skin flaps rotasi.

\section{MATERI DAN METODE}

Penelitian ini telah mendapat izin pelaksanaan penelitian dari Komisi Etik Fakultas Kedokteran Hewan Universitas Syiah Kuala dengan nomor 49/KEPH/X/2019. Penelitian ini menggunakan enam ekor kucing lokal jantan yang dinyatakan sehat secara klinis. Kucing diadaptasikan selama 2 minggu dalam kandang individu diberi makan 2 kali sehari dan air minum ad libitum. Kucing dibagi menjadi 2 kelompok perlakuan, kelompok 1 dirawat dengan perban kassa steril dan kelompok 2 dengan perban framycetin sulfate (Sofra-Tulle®, Pantheon UK Limited, Swidon, UK for Sanofi-Aventis, Thailand). Kucing dipuasakan selama 8 jam kemudian dipremedikasi dengan atropin sulfat 0.02-0.04 $\mathrm{mg} / \mathrm{kg}$ BB SC dan kombinasi ketamin 10\% 10$40 \mathrm{mg} / \mathrm{kg}$ BB IM dan xylazine 2\% 1-4 mg/kb BB IM digunakan sebagai anastesi umum (Tilley dan Smith, 2005). Kucing yang telah memasuki tahap anastesi diposisikan lateral recumbency, kemudian, dilakukan pencukuran rambut dan desinfeksi. Kulit lateral abdomen antara os sacrum dan os femur diincisi untuk pembuatan luka segitiga dengan luas $2 \mathrm{~cm}^{2}$. Sumber flaps semisirkuler dari kulit abdomen, undermining kemudian flaps dirotasi hingga mampu menutupi luka. Kulit dijahit dan area flaps rotasi ditutup menggunakan perban sesuai kelompok perlakuan. Pengambilan darah sebanyak $1 \mathrm{ml}$ pada vena cephalica antebrachii dan dimasukkan ke dalam vacuum tab berisi antikoagulan EDTA (Furman et al., 2014). Pengambilan darah dilakukan pada hari ke-0 sebelum, hari ke-3, 6, dan 12 setelah skin flaps dilakukan.

\section{ANALISIS PROFIL DARAH}

Pemeriksaan profil darah dilakukan dengan menggunakan mesin penghitung otomatis hematology analyzer $\left(\right.$ Mindray $^{\circledR}$, Shenzen, China).

\section{ANALISIS DATA}

Data hasil penelitian dianalisis dengan ANAVA multivarian menggunakan program SPSS 21.

\section{HASIL DAN PEMBAHASAN}

Profil darah menggambarkan kondisi tubuh hewan secara sistemik sehingga menjadi parameter dalam keberhasilan teknik skin flaps (Erwin et al., 2017). Pengamatan profil darah bertujuan untuk melihat perubahan sistemik yang terjadi setelah bedah skin flaps. Profil darah yang diamati meliputi eritrosit, leukosit, hemoglobin, hematokrit, trombosit, dan diferensial leukosit selama proses kesembuhan luka pada tiap-tiap hari pengamatan. 

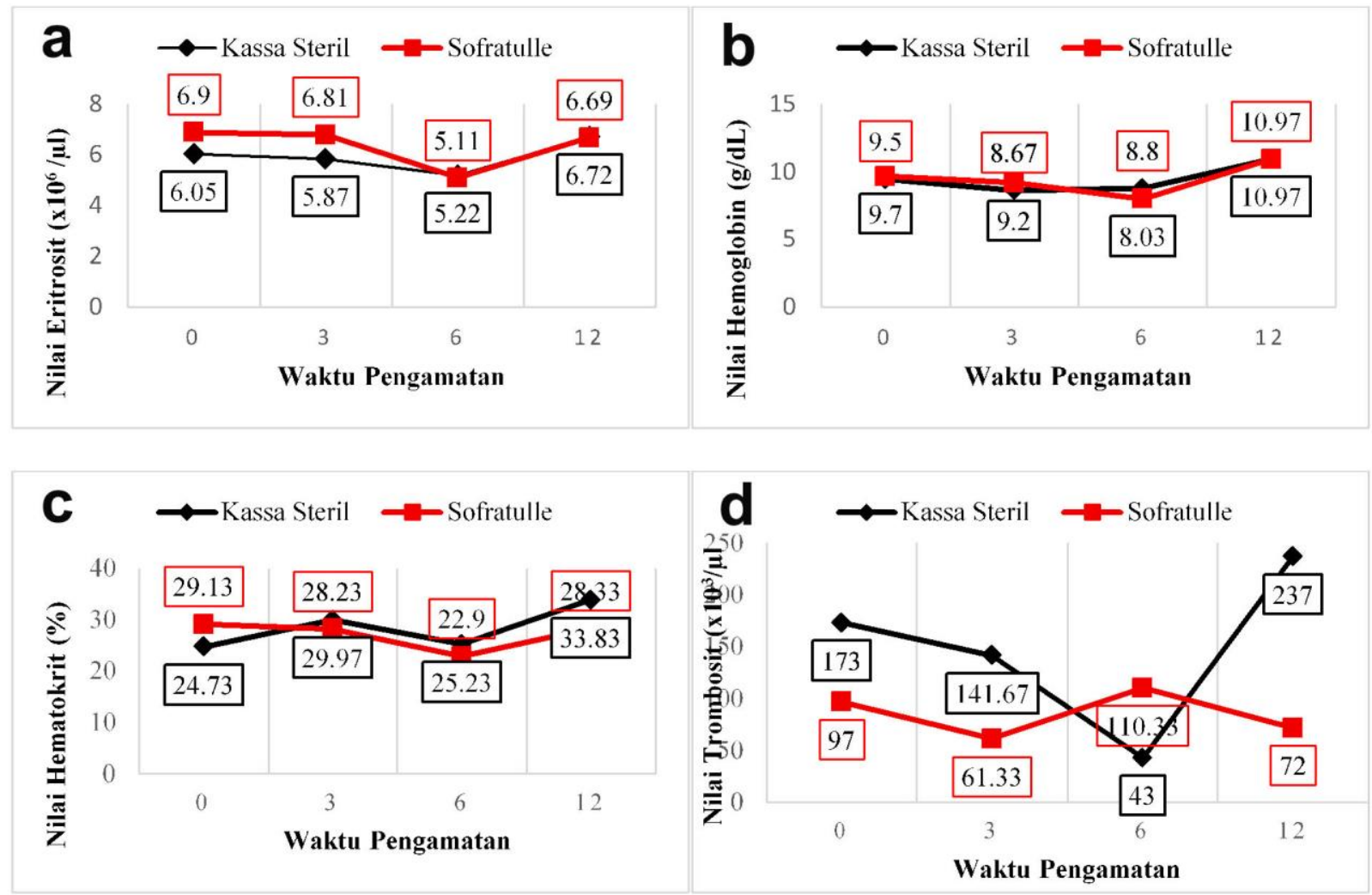

Gambar 1. Hasil pengukuran hematologi kedua kelompok perlakuan selama proses kesembuhan skin flaps rotasi pada hari ke-0, ke-3, ke-6, dan ke-12. (a) eritrosit, (b) hemoglobin, (c) hematokrit,

\section{(d) trombosit, (e) leukosit.}

\section{ERITROSIT}

Jumlah eritrosit antara kelompok perlakuan kassa steril (P-1) dan sofratulle ${ }^{\circledR}(\mathrm{P}-$ 2) menunjukkan perbedaan yang tidak signifikan $(\mathrm{P}>0,05)$. Penurunan eritrosit pada hari ke-3 dan 6 setelah skin flaps masih dalam nilai normal. Nilai normal eritrosit kucing menurut Triastuty (2006), adalah 4.09$8.15 \times 10^{6} / \mu 1$. Rata-rata jumlah eritrosit P-1 meningkat pada hari ke-12 setelah skin flaps dengan perbedaan yang signifikan $(\mathrm{P}<0,05)$ terhadap hari ke-0,3, dan 6 setelah skin flaps. Hasil pengamatan jumlah eritrosit kedua kelompok terdapat pada Gambar 1a.

Jumlah eritrosit pada kedua kelompok perlakuan menurun pada hari ke-3 dan 6 setelah skin flaps. Penurunan jumlah eritrosit terjadi akibat luka akut saat incisi kulit untuk skinflaps rotasi sehingga menyebabkan terpotongnya pembuluh darah dan jaringan. Penurunan jumlah eritrosit juga disebabkan karena fase inflamasi yang terjadi pada hari 3-6 setelah terjadinya luka (Erwin, 2019). Pada hari ke-12 antara kelompok perlakuan kassa steril (P-1) dan sofratulle ${ }^{\circledR} \quad(\mathrm{P}-2)$ jumlah eritrosit meningkat. Peningkatan jumlah eritrosit karena hari 12 dan 24 setelah skin flaps tubuh mencoba memulihkan kondisi fisiologis (Erwin et al., 2017).

\section{HEMOGLOBIN}

Jumlah hemoglobin antara kelompok perlakuan kassa steril (P-1) dan sofratulle ${ }^{\circledR}(\mathrm{P}-$ 2) menunjukkan perbedaan yang tidak signifikan $(\mathrm{P}>0,05)$. Rata-rata jumlah hemoglobin pada hari ke-3 dan ke-6 setelah skin flaps mengalami penurunan. Nilai normal hemoglobin kucing adalah 5.6-13.78 g/dl (Triastuty, 2006). Hasil pengamatan jumlah hemoglobin pada kedua kelompok terdapat pada Gambar 1b.

Hemoglobin merupakan pigmen pembawa oksigen (Mc Curnin dan Bassert, 2006) yang menjadi parameter mengukur keadaan anemia (Cunningham dan Klein, 2007). Nilai hemoglobin berbanding lurus dengan eritrosit sehingga peningkatan jumlah hemoglobin mengindikasikan peningkatan jumlah eritrosit (Indrianti et al., 2015). Penurunan nilai 
hemoglobin di bawah kisaran normal dapat menyebabkan hipoksia dan diakhiri dengan kematian jaringan jika berlangsung dalam jangka yang panjang (Erwin et al., 2017).

\section{HEMATOKRIT}

Persentase hematokrit antara kelompok perlakuan kassa steril (P-1) dan sofratulle ${ }^{\circledR}(\mathrm{P}-$ 2) tidak menunjukkan perbedaan yang signifikan $(\mathrm{P}>0,05)$. Hasil pengamatan jumlah hematokrit kedua kelompok terdapat pada Gambar 1c.

Persentase nilai normal hematokrit pada kucing adalah 15.76-36.4\% (Triastuty, 2006). Pada kelompok perlakuan kassa steril (P-1) dan sofratulle $^{\circledR}(\mathrm{P}-2)$, rata-rata jumlah hematokrit masih dalam nilai normal. Hal ini mengindikasikan hewan tidak mengalami anemia. Sesuai dengan pernyataan Erwin et al. (2017) bahwa pemeriksaan hematokrit dilakukan untuk mengidentifikasi adanya anemia. Penurunan jumlah hematokrit kedua kelompok pada hari ke-6 setelah skin flaps disebabkan hewan mengalami stres. Stres akibat rasa sakit setelah bedah skin flaps rotasi yang menyebabkan penurunan nafsu makan dan keinginan minum (Fowler, 2006). Menurut Erwin et al., (2016) kehilangan cairan menyebabkan penurunan nilai hematokrit. Nilai hematokrit berpengaruh dalam proses penyembuhan luka, karena hematokrit mengandung oksigen. Jumlah hematokrit yang tercukupi maka proses penyembuhan luka berjalan dengan baik (Gottrup, 2004).

\section{TROMBOSIT}

Jumlah trombosit antara kelompok perlakuan kassa steril (P-1) dan sofratulle ${ }^{\circledR}(\mathrm{P}-$ 2) menunjukkan perbedaan yang tidak signifikan $(\mathrm{P}>0,05)$. Jumlah trombosit antar kelompok perlakuan mengalami perubahan yang berfluktuasi pada tiap-tiap hari pengamatan dengan perbedaan yang tidak signifikan $(\mathrm{P}>0,05)$. Nilai normal trombosit pada kucing adalah $86-484 \times 10^{3} / \mu 1$ (Triastuty, 2006). Hasil pengamatan jumlah trombosit kedua kelompok terdapat pada Gambar 1d.

Pada hari ke-3 setelah skin flaps terjadi penurunan jumlah trombosit karena trombosit menuju tempat luka untuk menghentikan pendarahan (Erwin et al., 2016). Jumlah trombosit pada kelompok perlakuan kassa steril (P-1) terus menurun hingga hari ke-6 setelah skin flaps hal ini menunjukkan fase hemostasis pada kelompok perlakuan kassa steril (P-1) lebih lama dibandingkan kelompok perlakuan sofratulle $^{\circledR}(\mathrm{P}-2)$. Namun, jumlah trombosit mengalami peningkatan kembali pada hari ke12 setelah skin flaps. Hal ini menunjukkan bahwa tubuh merespon akibat terjadinya penurunan trombosit dalam sirkulasi darah (Keohane et al., 2015). Jumlah trombosit yang menurun kembali pada hari ke-12 setelah skin flaps pada kelompok perlakuan sofratulle ${ }^{\circledR}(\mathrm{P}$ 2) dikarenakan jumlah trombosit dalam sirkulasi darah hewan normal selalu dalam keadaan dinamis (Erwin et al., 2017).

\section{LEUKOSIT}

Rata-rata jumlah leukosit antara kelompok perlakuan kassa steril (P-1) dan sofratulle ${ }^{\circledR}(\mathrm{P}-$ 2) menunjukkan perbedaan yang tidak signifikan $(\mathrm{P}>0,05)$. Pada kelompok perlakuan kassa steril (P-1) jumlah leukosit meningkat pada hari ke 3,6, dan 12 setelah skin flaps. Pada kelompok perlakuan sofratulle ${ }^{\circledR}(\mathrm{P}-2)$ jumlah leukosit mengalami peningkatan pada hari ke-3 setelah skin flaps. Hari ke-6 dan 12 setelah skin flaps jumlah leukosit kembali menurun, namun masih dalam kisaran nilai normal. Total leukosit normal pada kucing adalah 5.5$19.5 \times 10^{3} / \mu 1$ (Feldman et al., 2000). Hasil pengamatan jumlah leukosit kedua kelompok terdapat pada Gambar 2a. 

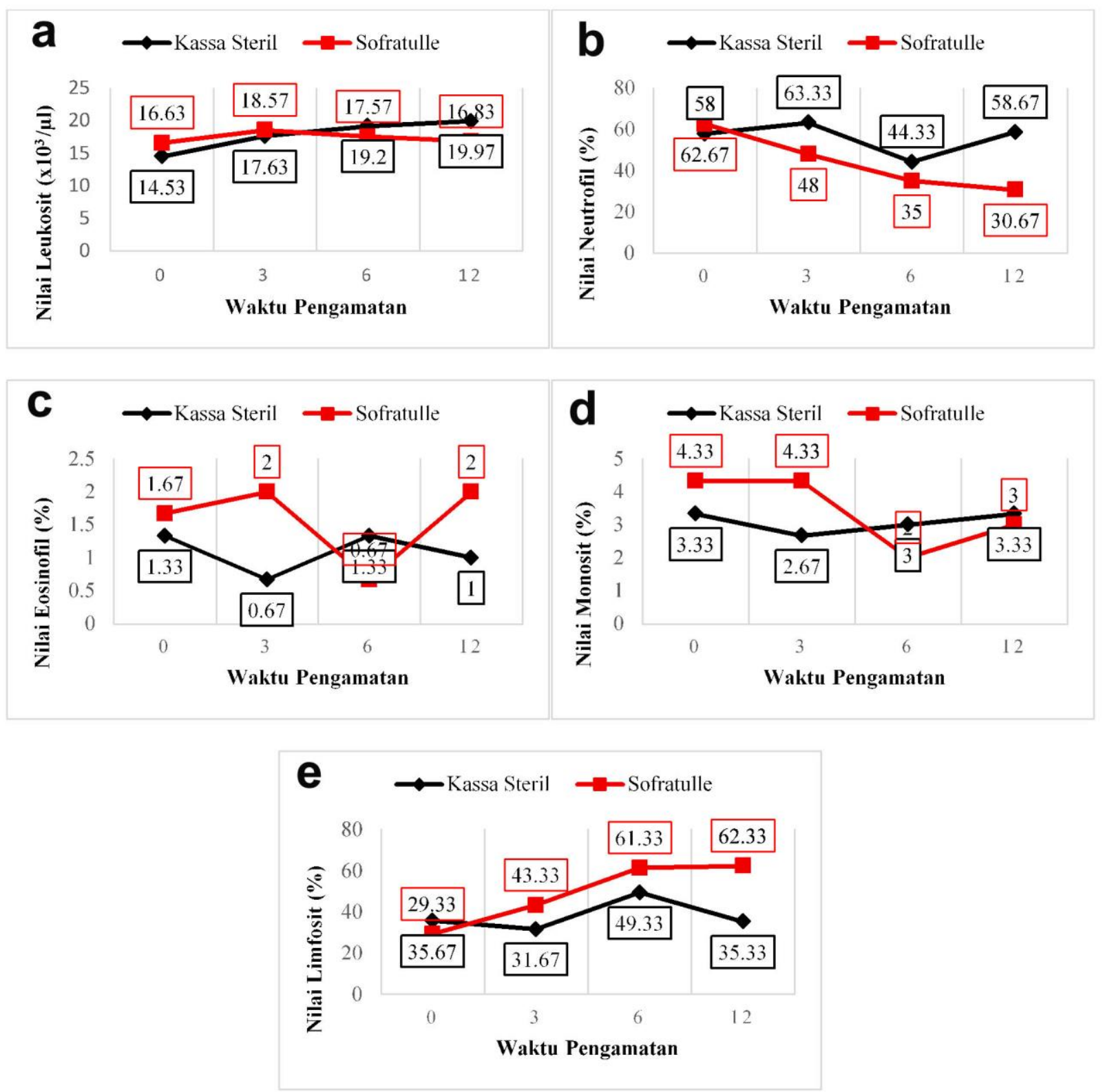

Gambar 2. Hasil pengukuran hematologi kedua kelompok perlakuan selama proses kesembuhan skin flaps rotasi pada hari ke-0, ke-3, ke-6, dan ke-12. (a) leukosit, (b) neutrofil, (c) eosinofil, (d) monosit, (e) limfosit

Peningkatan leukosit pada hari ke-3 setelah skin flaps akibat terdapatnya hormon kortisol di dalam darah. Keadaan stress menstimulasi munculnya adrenalin yang memicu pergerakan leukosit dari MGP (Marginal Granulosit Pool) menuju CGP (Circulating Granulosit Pool) sehingga terjadi peningkatan leukosit dalam sirkulasi darah. Peningkatan jumlah leukosit sebagai bentuk fisiologis tubuh untuk memfagosit antigen asing (Erwin et al., 2017). Fase inflamasi yang berlangsung sejak terjadinya luka hingga hari ke-6 menunjukkan penurunan leukosit ditandai migrasi sel leukosit ke daerah luka (Erwin, 2019). Jumlah leukosit pada kelompok perlakuan kassa steril (P-1) terus meningkat hingga hari ke-12 setelah skin flaps, berbeda dengan kelompok perlakuan sofratulle $^{\circledR}$ (P-2) jumlah leukosit mengalami penurunan. Hal ini sesuai dengan pernyataan (Casey, 2000) fase inflamasi dapat terjadi lebih singkat jika tidak terjadi infeksi.

\section{NEUTROFIL}

Jumlah neutrofil pada kelompok perlakuan kassa steril (P-1) dan sofratulle ${ }^{\circledR}$ (P-2) menunjukkan perbedaan yang signifikan $(\mathrm{P}<0,05)$. Rata-rata jumlah neutrofil kelompok perlakuan kassa steril (P-1) mengalami 
fluktuasi. Nilai normal neutrofil adalah 35-75\% (Feldman et al., 2000). Rata-rata jumlah neutrofil kelompok perlakuan sofratulle ${ }^{\circledR}(\mathrm{P}-2)$ menurun pada hari ke-3, 6 dan 12 dengan perbedaan yang signifikan $(\mathrm{P}<0,05)$. Hasil pengamatan jumlah neutrofil kedua kelompok terdapat pada Gambar 2b.

Neutrofil memfagosit benda asing dan mikroorganisme terutama bakteri pada luka (Anderson, 2001) selama tiga hari (Erwin, 2019). Jumlah neutrofil akan meningkat 24 jam - 36 jam setelah terjadi luka (Primadina et al., 2019). Jumlah neutrofil yang meningkat disebabkan infeksi bakteri akut. Persentase neutrofil pada kelompok kassa steril (P-1) meningkat pada hari ke-3 dan 12 setelah skin flaps. Tidak adanya dekontaminasi yang efektif memperpanjang fase inflamasi. Hal ini dipicu keberadaan mikroba selama perawatan (Guo and Dipietro, 2010).

Persentase neutrofil pada kelompok perlakuan sofratulle ${ }^{\circledR}(\mathrm{P}-2)$ menurun hari ke-3, 6, dan 12 setelah skin flaps. Hal ini menunjukkan perawatan luka dengan sofratulle $^{\circledR}$ mengurangi resiko infeksi. Sofratulle ${ }^{\circledR}$ mengandung antibiotik (framycetin sulphat $1 \%$ ), yang dapat mengendalikan infeksi sekunder (Carville, 2012). Kartika (2015) menyatakan resiko infeksi perawatan luka dengan suasana lembab relatif lebih rendah dibandingkan dengan perawatan suasana kering.

\section{BASOFIL}

Jumlah basofil pada kelompok perlakuan kassa steril (P-1) dan sofratulle ${ }^{\circledR}(\mathrm{P}-2)$ tidak ditemukan. Persentase normal basofil pada kucing adalah 0-1 \% (Feldman et al., 2000). Basofil memiliki peran penting pada reaksi alergi (Ganong, 2013), tidak ditemukan basofil menunjukan bahwa tidak terdapat reaksi alergi dalam tubuh akibat perawatan skin flaps rotasi dengan kassa steril dan sofratulle ${ }^{\circledR}$.

\section{EOSINOFIL}

Persentase eosinofil antara kelompok perlakuan kassa steril dan sofratulle ${ }^{\circledR}$ menunjukkan perbedaan yang tidak signifikan $(\mathrm{P}>0,05)$. Eosinofil pada kedua kelompok perlakuan mengalami perubahan yang berfluktuasi pada tiap-tiap hari pengamatan. Hasil pengamatan jumlah eosinofil kedua kelompok terdapat pada Gambar 2c
Persentase eosinofil normal kucing yaitu 212\% (Feldman et al., 2000). Kondisi eosinofilia seringkali terjadi pada penderita infeksi parasit (Campbell, 2004). Persentase eosinofil pada kelompok perlakuan kassa steril (P-1) mengalami penurunan pada hari ke-3 setelah skin flaps, naik kembali pada hari ke-6 kemudian turun pada hari ke-12 setelah skin flaps. Fluktuasi eosinofil disebabkan peran eosinofil terhadap respon inflamasi. Eosinofil mampu mengatur respon inflamasi lokal dan akumulasinya di dalam aliran darah maupun di jaringan (Fulkerson dan Rothenberg, 2013).

\section{MONOSIT}

Persentase monosit antara kelompok perlakuan kassa steril (P-1) dan sofratulle ${ }^{\circledR}(\mathrm{P}-$ 2) menunjukkan perbedaan yang tidak signifikan $(\mathrm{P}>0,05)$. Persentase monosit normal pada kucing adalah 1-4 \% (Feldman et al., 2000). Persentase monosit kelompok perlakuan sofratulle $^{\circledR}$ pada hari ke-0 sebelum skin flaps berbeda signifikan $(\mathrm{P}<0,05)$ dengan hari ke-6 dan 12 setelah skin flaps. Hasil pengamatan jumlah monosit pada kedua kelompok terdapat pada Gambar 2d.

Kerusakan jaringan akibat penyayatan kulit flap rotasi menimbulkan reaksi persembuhan luka yang diawali dengan inflamasi akut (Erwin et al., 2017). Persentase monosit kelompok perlakuan kassa steril (P-1) menurun pada hari ke-3 setelah skin flaps. Pada hari ke-3 luka, monosit bermigrasi ke jaringan dan berdiferensiasi menjadi makrofag (Nucera et al., 2010). Peningkatan persentase monosit pada hari ke-6 dan ke-12 setelah skin flaps menunjukkan respon tubuh terhadap agen infeksi (Primadina et al., 2019). Persentase monosit pada hari ke-3 setelah skin flaps kelompok perlakuan sofratulle ${ }^{\circledR}$ (P-2) tidak mengalami perubahan. Kandungan framycetin sulfate $1 \%$ pada sofratulle ${ }^{\circledR}$ dapat mengendalikan infeksi sekunder (Carville, 2012) sebagaimana peran monosit memfagosit bakteri dalam penyembuhan luka (Primadina et al., 2019).

\section{LIMFOSIT}

Persentase limfosit pada kelompok perlakuan kassa steril (P-1) dan sofratulle ${ }^{\circledR}(\mathrm{P}-$ 2) menunjukkan perbedaan yang tidak signifikan $(\mathrm{P}>0,05)$. Persentase limfosit kelompok perlakuan sofratulle ${ }^{\circledR} \quad(\mathrm{P}-2)$ 
mengalami peningkatan pada hari ke-3,6, dan 12 setelah skin flaps dengan perbedaan signifikan $(\mathrm{P}<0,05)$ antara hari ke-0 sebelum skin flaps dengan hari ke-6 dan 12 setelah skin flaps. Hasil pengamatan jumlah limfosit kedua kelompok terdapat pada Gambar 2e.

Peningkatan dan penurunan limfosit berkaitan dengan respon imunitas tubuh. Peningkatan jumlah limfosit pada kelompok perlakuan kassa steril (P-1) terjadi pada hari ke6 setelah skin flaps sedangkan kelompok perlakuan sofratulle ${ }^{\circledR}$ (P-2) jumlah limfosit meningkat pada hari ke-3,6 dan 12 setelah skin flaps. Kartika (2015) menyatakan bahwa pada keadaan lembab invasi limfosit ke daerah luka berlangsung lebih dini. Menurut Landen et al. (2016), limfosit, neutrofil dan makrofag adalah sel yang pertama kali mencapai daerah luka. Limfosit memiliki peran dalam mengatur perilaku monosit dan makrofag pada reaksi benda asing.

Dressing pada luka membantu proses reepitelisasi lebih cepat, sintesis kolagen dan angiogenesis (Sujatha, 2012). Kandungan senyawa kimia berbeda dari setiap dressing berpengaruh terhadap kesembuhan luka. Setiap dressing memiliki kelebihan dan kekurangannya, penggunaan dressing yang tepat sesuai kondisi luka mempercepat kesembuhan luka (Dhivya et al., 2015). Dressing yang ideal untuk kesembuhan luka yaitu mampu menciptakan lingkungan lembab, menyerap eksudat yang berlebihan, mencegah infeksi, mengurangi nyeri, mencegah trauma lanjutan, mengontrol perdarahan dan non alergic (Wijaya, 2018).

\section{KESIMPULAN}

Perawatan skin flaps rotasi menggunakan dry dressing dan moist dressing berpengaruh terhadap proses kesembuhan luka. Profil neutrofil menunjukkan kesembuhan luka moist dressing pada hari ke-12 sedangkan perawatan luka dry dressing menunjukkan peradangan yang berkepanjangan

\section{UCAPAN TERIMAKASIH}

Terimakasih penulis ucapkan kepada Dekan Fakultas Kedokteran Hewan Universitas Syiah Kuala.

\section{DAFTAR PUSTAKA}

Anderson, J.M. (2001). Biological responses to materials. Annu. Rev. Mater. Res, 31: 81110.

Boateng, JS., Matthews, KH., Stevens, H.N.E. and Eccleston, G.M. (2008). Wound healing dressings and drug delivery systems : a review. Indian. J. Pharm. Sci, 97 (28) : 922-923.

Campbell, T.W. (2004). Mammalian Hematology: Laboratory Animals And Miscellaneous Species, Philadelphia

Carville, K. (2012). Wound Care Manual $6^{\text {th }}$ Edition. Silver Chain Foundation, Western Australia.

Casey, G. (2000). Modern wound dressing. Nurs. Stand, 15(5) : 47-51.

Cunningham, J.G and Klein, B.G. (2007). Texbook of Veterinary Physiology. Ed ke-4. Saunders Elsivier, Missouri (US).

Dhivya, S., Padma, V.V and Santhini, E. (2015). Wound dressings- a review. Biomedicine, 5 (4) : 24-28

Erwin, (2019). Ilmu Bedah Hewan Kecil. Syiah Kuala University Press, Banda Aceh.

Erwin, Gunanti, Handharyani, E., and Noviana, D. (2017). Blood profile of domestic cat (Felix catus) during skin graft recovery with different period. Jurnal Veteriner, 18(1): 31-37.

Erwin, Gunanti., Handharyani, E. and Noviana, D. (2016). Subjective and objective observation of skin graft recovery on Indonesia local cat with different periods of transplantation time. Vet. Word, 9(5): 481486.

Erwin, Noviana, D., Gunanti, dan Putra, I.G.A.N.A.E. (2016). Kesembuhan skin flap h-plasty dan linear closure untuk penutupan luka area lateral thoraks. Jurnal Sain Veteriner, 34 (2) : 203-208.

Feldman, B.F., Zinkl, J.G., Jain, N.C., and Schalm, O.W. (2000). Schalm`s Veterinary Hematology. Lippincot Williams \& Wilkins, Philadelphia (US).

Fowler D. (2006). Distal limb and paw injuries. Vet Clin North Am Small Anim Pract 36(4): 819-845.

Furman, E., Leidinger, E., Hooijberg, E.H., Bauer, N., Beddies, N. and Moritz, A. (2014). A Retrospective study of 1098 
blood samples with anemia from adult cats: frequency, classification, and association with serum creatinine concentration. J.Vet. Intern. Med, 28(5): 1391-1397.

Fulkerson, P. C. and Rothenberg, M. E. 2013. Targeting eosinophils in allergy, inflammation and beyond. Nature Reviews Drug Discovery, 12: 117-129

Galiano, R.D. (2007). Topical vascular endothelial growth factor accelerates wound healing through increased angiogenesis and by mobilizing and recruiting bone marrow-derived cells. $J$. Pathol, 16 (4) : 1935-1947

Ganong, W.F. (2013). Buku Ajar Fisiologi Kedokteran, edisi ke-20. EGC, Jakarta

Gottrup, F. (2004). Oxygen in wound healing and infection. Word of Journal Surgery, 28(3): 312-315.

Guo, S. and Dipietro, L.A. (2010). Factors affecting wound healing. J. Den. Res, 89(3): 219-229.

Indrianti, M. D., Tana, S., dan Mardiati, S. M. (2015). Hematologi kelinci (Lepus sp.) setelah perlakuan implantasi material stainless steel aisi 3161 selama 2,5 bulan. Buletin Anatomi dan Fisiologi, 23(2): 85.

Kamoun, E.A., Kenawy, E.R. and Chen, X. (2017). A review on polymeric hydrogel membranes for wound dressing applications : PVA-based hydrogel dressings. Journal of Advanced Research, 8(1): 218-223

Kartika, R.W. (2015). Perawatan luka kronis dengan modern dressing. Cermin Dunia Kedokteran, 42(7) : 546-549.

Keohane, E.M., Smith, L.J., and Walenga, J.M. (2015). Rodaks's Hematology: Clinical Principles and Applications 5th Ed. St. Louis. Elsevier

Landen, N.X., Li, D., and Stahle, M. (2016). Transition from inflammation to proliferation : a critical step during wound healing. Cellular and Molecular Life Sci, 73(20): 3861-3885.
Langley-Hobbs, S.J., Demetriou, J.L, and Landlow, J.F. (2014). Feline Soft Tissue And General Surgery. Saunders Elevier, New York.

Lawrence, M. dan Tierney, J. (2002). Diagnosis dan Terapi Kedokteran (Penyakit Dalam). Salemba Medika, Jakarta.

Mast, A.B. (2000). Normal Wound Healing Plastic Surgery, Indications, Operations and Outcomes. Mosby, St Louis (US).

Mc Curnin, D.M. and Bassert, J.M. (2006). Clinical Textbook for Veterinary Technicians 6 th Ed. Elsevier, Ames (US).

Nucera, S., Biziato, D. and Palma, M.D. (2010). The interplay between macrophages and angiogenesis in development tissur injury and regeneration. Int.J.Dev.Biol, 55 : 495503.

Primadina, N., Basori, A. dan Perdanakusuma, D.S. (2019). Proses penyembuhan luka ditinjau dari aspek mekanisme seluler dan molekuler. Qanun Medika, 3 (1) : 31-38.

Schulitz, G., Mozingo, D., Romanelli, M. and Claxton, K. (2005). Wound healing and TIM new concepts and scientific applications. Wound Repair and Regeneration, 13 (4) : 1-11.

Smith, K. (2010). Soft tissue surgery. Malaysian Small Animal Veterinary Association, Selangor .

Sujatha S. (2012). Recent advances in topical wound care. Indian J. Plast. Surg, 45: 87379.

Tilley, L. P. and Smith, F. W. K. (2011). Blackwell's Five-minute Veterinary Consult Canine and Feline 5th Edition. Wiley-Blackwell, London.

Triastuty, F.N. (2006). Gambaran darah Kucing Kampung di Daerah Bogor. Skripsi. Fakultas Kedokteran Hewan. Institut Pertanian Bogor. Bogor.

Wijaya, I.M.S. (2018). Perawatan Luka Dengan Pendekatan Multidisiplin. Penerbit Andi, Yogyakarta. 